\title{
Al-Azhar University and pre-university Education after Development law in 1961
}

\author{
Ashraf Mohamed Abdul Rahman', Samah Mahmoud ${ }^{2}$, Abd Elrahim Ahmed ${ }^{3 *}$ \\ ${ }^{1}$ History Department, Faculty of Education, Ain Shams University, Cairo, Egypt \\ ${ }^{2}$ Tourist Guidance Department, Faculty of Tourism and Hotels, Minia University, Minia, Egypt \\ ${ }^{3}$ Modern and Contemporary History, Faculty of Tourism and Hotel Management, Minia University, Al-Minia, Egypt \\ * Correspondence: abdelraheamhamed@gmail.com; Tel: +2 01155521209
}

\section{Article information}

Received: 13 September 2020

Revised: 4 October 2020

Accepted: 4 October 2020

\section{Key words}

Development law, Al-Azhar University, preuniversity Education, Azharite institute

\begin{abstract}
One of the most important results of Development law No. 103 of 1961 was the establishment of the modern independent Al-Azhar University. The development law led to the increase and diversity in the number of colleges in Al-Azhar University between theoretical and practical such as engineering faculty, medicine faculty, agriculture faculty and the faculty for girls etc in addition to College of Fundamentals of Religion, College of Sharia and Law and College of the Arabic Language. The development law also led to spreading the Azharite institutes in African countries The Egyptian government also provided the African students with all support and facilities. The research presented Al-Azhar University Spending Rate from 1962 to 1978 and p presented also the number of Students of Al-Azhar University before and after the Development law 1961, distributed according to their colleges, including those that were established late. The Conditions of joining Al-Azhar Institutes was mentioned in the research.
\end{abstract}

\section{Al-Azhar University}

Al-Azhar University is specialized in everything related to higher education in Al-Azhar and the researches relevant to this education. The Development Law in Al-Azhar, after the July 1952 Revolution, had many important outcomes. These included the establishment of the modern independent Al-Azhar University according to the provisions of Law No. 103 of 1961, and appointing its president by a decision of the President of the Republic upon the nomination of the competent minister and the proposal of Sheikh Al-Azhar. Consequently, new colleges were established for different sciences such as engineering, medicine and other colleges which contributed to the development of AlAzhar. This law also aimed to provide Al-Azharwith a broader opportunity to serve the Islamic call [1]. It stipulated replacing the articles of Law No. 26 of 1936 with other provisions reorganizing Al-Azhar Mosque and their amendments by Law No. 103 of 1961 regarding the reorganization of Al-Azhar and its bodies. It also abolished all provisions contradicting the new law [2] .

Al-Azhar University, according to the stipulations of the Law of Reorganization of Al-Azhar, has some basic functions. These are as follows.

(A) A civilized educational function: represented by higher education in the university's colleges, preserving and disseminating the Islamic heritage, qualifying the religious world to participate in all kinds of activities and production of the world to participate in calling to the path of God, especially in African countries.
(B) A special function of the call to Islam: to provide the Islamic and Arab world with scholars to perform the service of the Islamic Call [1163] .

Al-Azhar University is considered a university for Muslims from all parts of the world, and it treats the Egyptian students and international students alike in all its colleges in terms of admission opportunities and free education as all are students in its colleges. They are educated the same curricula, in the same courses with the same hours. They differ only in the preparatory and qualifying stages. Sometimes, there is a specific rate for expatriates' admission to each college, which may be $10 \%$. AlAzhar University pays great interest to the African students, so each official according to his/her specialty provides assistance to them[4] .

Law No. 103 of 1961 AD defined in Article No. (33) The objectives and specialties of Al-Azhar University as follows:

- Al-Azhar University is concerned with everything related to higher education in Al-Azhar and research related to this education.

- It is concerned with preserving, studying, manifesting and disseminating the Islamic heritage.

- It informs people with the message of Islam and works to show its truth and impact on the progress of human beings and ensuring their happiness in this world and the hereafter.

- It is interested in reviving Arab civilization and the scientific, intellectual and spiritual heritage of the Arab nation.

- It works to provide the Islamic and Arab world with scholars who combine faith in God, self-confidence, spirituality, and deep understanding of belief, law, and the language of the Qur'an, scientific and professional sufficiency to confirm the 
relation between religion and life on the one hand and belief and behavior on the other.

- Qualifying the Muslim clergy to participate in all kinds of activities, production, and leadership to show the good example. In addition, they are qualified to participate in the call for the path of God with wisdom and good advice inside Egypt and abroad, whether they were Egyptians or not.

- It is concerned with strengthening cultural and scientific relations with Islamic, Arab and foreign universities and organizations[1].

The jobs hierarchy of Al-Azhar University is as follows: The President of Al-Azhar University is appointed by a presidential decree based on a nomination of the Minister of Al-Azhar Affairs and the proposal of Sheikh al-Azhar. He has to be a professor at Al-Azhar University or one of the universities in Egypt [5]. The university deputies, the secretary of the university, and the deans of colleges are appointed by a Presidential decree based on the proposal of the competent minister and the proposal of the university president as well as the approval of Sheikh Al-Azhar. The same aforementioned conditions apply to assigning the deputy. Al-Azhar University confers the honorary degree of "Al-'Alameya" only based on the proposal of its council and with the approval of the Supreme Council of Al-Azhar, and issuing a decision of the President of the Republic [6].

The development law led to the increase and diversity in the number of colleges in Al-Azhar University between theoretical and practical based on the exact specialization, which was absent before. These colleges are as follows: -

(1) College of Fundamentals of Religion: It has departments for the Qur'an, a department for the Sunnah and its sciences, a department for monotheism and philosophy and a department for ethics and sociology.

(2) College of Sharia and Law: It has departments for Islamic jurisprudence, the fundamentals of jurisprudence and comparative jurisprudence.

(3) College of the Arabic Language: It includes the linguistics department, the literary department, the philology department, the rhetoric origins department, the language origins section, the history and civilization department, the European and Eastern languages department.

(4) Faculty of Commerce: It is concerned with Transactions and Management. It teaches business administration, accounting, economics, mathematics, statistics, law, Islamic studies and other sciences.

(5) Faculty of Engineering: It has eight departments: Electrical Engineering; Mechanical Engineering, Civil Engineering, Mining and Petroleum, Architecture and Planning, Basic Sciences, Chemical Engineering and at last the Department of Clothing and Textile).

(6) Faculty of Medicine: It has various departments of medicine, as is the case with other faculties of medicine in Egypt, in addition to the Islamic Studies curriculum that was developed to qualify the graduate as an Islamic educated doctor.

(7) Faculty of Agriculture: It has agricultural departments, as is the case in the faculties of agriculture in Egypt.

(8) Faculty for Girls: It has several departments, namely: Department of Arabic and Islamic Studies, Department of Psychological and Social Studies, Department of Languages and Translation, Department of Commerce, Department of Medicine and Surgery, which became a separate college in 1964 AD [7].

All of these colleges, regardless of their specializations, teach multiple Islamic studies as basic subjects, and this is a distinct feature of Al-Azhar University from all other universities. Other colleges or higher institutes may be established by a decision of the President of the Republic, and each college consists of some departments, each of which undertakes teaching subjects that fall within its specialization. It performs researches whether in the college or in other colleges and institutes of the university. These departments are established by a decision of the competent minister. It is not allowed to establish similar departments in the university colleges. The executive regulations of this law determine the departments that follow each of these colleges, the types of studies, the degrees granted by the university from these colleges[1] .

Law No. 103 of 1961 AD stipulated also that it is permissible to establish institutes affiliated with colleges if the study in them relates to more than one of the departments. The provisions pertaining to the college departments apply to these institutes. University colleges or some of them may be attached to educational schools for subjects or studies related to Al-Azhar purposes, such as the school for the recital of the Holy Qur'an and teaching its readings, or general counseling departments to meet the needs of those seeking more religious, Arabic and other information of the commons. These schools and departments are not subject to university study conditions, and the executive regulations specify the system of their work [1].

Law No. 103 of 1961 AD is considered one of the best laws that helped in developing Al-Azhar Al-Sharif, in order to fully carry out the mission entrusted to it. Its outcomes included establishing the independent modern Al-Azhar University, its new colleges in various scientific areas to spread the message of Al-Azhar in the religious and worldly sciences. These included the Faculty of Medicine, Engineering and other colleges. As for the colleges of the University of Al-Azhar, the development law that colleges are based on accurate specialization, which was not present before. For example, the College of Arabic language managed to teach (logic, personal status, jurisprudence, fatwa), and faculty of Sharia that teaches (rhetoric, literature, and grammar) [8].

Despite some people did not support this law and saw it as a reason of Al-Azhar delay, others believed that this law had a positive impact on Al-Azhar. These included Dr. Muhammad Al-Bahi [9] who explained the importance of this law. He stated 
that despite its defects, the establishment of new colleges, in addition to the three traditional colleges at Al-Azhar University, is a great opportunity for the Azharite scholars to direct their children to Al-Azhar institutes so that they maintain the direction of their parents in learning about Islam and accepting faith in it. At the same time, they can join the religious education in the primary, preparatory and secondary schools of Al-Azhar. Hence, the children of scholars will not deviate from their parents' directions and will not be deprived from higher education of scientific and practical specializations. This will add to what they have learned before. In addition, the establishment of these new colleges is also an opportunity for the Muslim young men and women who did not enroll in Islamic education to join civil education schools, which are the schools of the Ministry of Education. This will provide them with a good portion of Islamic study, and the necessary Arabic study with university education, before graduating and ending their educational life [10].

Al-Azhar University worked to conclude various scientific and cultural agreements with the universities of African countries, as one of its primary goals was the exchange of professors and students to exchange experience, scholarships and obtain high educational qualifications. The university works on exchanging books, publications, periodicals, cultural and educational films and exchanging exhibitions and Islamic Arts. Al-Azhar University also works to strengthen its ties with various African universities and cultural centers through the University President and the General Department for Scientific and Cultural Relations [11].

As for the degrees provided by Al-Azhar University, they are as follows:

First - The degree of high education accreditation for colleges and institutes and it is equivalent to a bachelor's degree in other universities in Egypt.

Second - The degree of specialization in one of the studies similar to that in other colleges, equivalent to a master's degree. Third - The degree of al-'Alameyaih any Islamic or Arabic study from one of the faculties of Islamic studies, and Arab studies for those with a high degree from them or from other colleges, equivalent to a $\mathrm{PhD}$.

Fourth: The degree of 'Alameyaih or $\mathrm{PhD}$ in any postgraduate studies from any other colleges[12] .

It is clear from the table number (1) that Al-Azhar University is one of the oldest and most prominent universities, so the Egyptian government was always keen on its development and increasing its allocations. This is evident in the yearly increase of these allocations. The budget of the university year $1963 / 1964$ is the greatest due to the great expansion in the construction of Al-Azhar University to complete its various buildings, its scientific and administrative personnel, and providing its requirements to be able to play its role. This allowed it to attract a larger number of students from home and abroad, especially from African countries. The budget of Al-
Azhar University was also affected by the then political and economic conditions in Egyptian during the sixties and the beginning of the seventies [14].

Therefore, it is clear that Al-Azhar University played a civilized and a preaching role to clarify the Islamic heritage from misconceptions. This is achieved through the curricula delivered to the students of theoretical colleges, so the Faculty of Fundamentals of Religion, for example, has developed a subject called "The Intruder in Interpretation", and another called "Extraction and Study of Proofs". IN 1977, the Department of Hadith at the Faculty of Fundamentals of Religion started a pioneering project known as the Sunnah Project. It consists of three phases; the first is concerned with surveying the hadiths that are circulated in printed or manuscript books. They amount to $(200,000)$ hadiths in about twenty books. It aims at determining the quality of the hadith (authentic, fair or weak). This work is carried out by graduate students, whereby a master's degree is specified for graduation and examination of about four hundred Hadiths, and the $\mathrm{PhD}$ thesis requires doing the same with one thousand and two hundred Hadiths. As for the second phase, it is the separation of authentic hadiths from others in separate books and the third includes choosing a collection of hadiths to cover the provisions of Sharia in one book [15].

Al-Azhar University has received invitations to participate in international scientific conferences from the Ministry of Foreign Affairs and scientific bodies in Africa. It sent specialists from members of the teaching staff to participate in modern researches and stand on modern scientific developments. These conferences included: The Conference of Directors of African Universities held in Khartoum from 16-19 September 1963 and the university was represented by Mohamed Ahmed Suleiman, the deputy of Al-Azhar University. It took part also in the Medical Education Conference held in Algeria from May 3-9, 1963, and the university was represented by Mr. Al-Tayeb Muhammad Saeed Al-Hadidy, the general superintendent of medical administration at the university[3] .

In March $1964 \mathrm{AD}$, the foundation stone was laid for the new Al-Azhar University buildings in Nasr City. The buildings of some colleges were opened such as the faculties of engineering and science, and work continued to accomplish the remaining buildings. The cost of these buildings is estimated by (LE. 250,000). They were designed on the latest styles, and include modern auditoriums and laboratories [16]

The Development Law allowed Al-Azhar University to study foreign languages to allow Al-Azhar graduates to learn Arabic and other languages that must be known. Thus, Al-Azhar graduate become able to learn about the cultures of other societies. In 1965, the University of Al-Azhar inaugurated the Faculty of Languages and Translation. It started with two departments for foreign languages, namely the English and French, then expanded to include twelve departments in 
addition to six for Islamic studies in foreign languages. As a result, its graduates became a link of communication between Al-Azhar and Africa. The Islamic centers of Al-Azhar abroad depend on the graduates of the Faculty of Languages and Translation, and the work of members of the faculty to translate the meanings of the Noble Qur'an, hadiths, Islamic history, heritage books and scientific encyclopedias as well as distributing them to various embassies[7 ،17] .

In view of the importance of communication relations with the African societies and their multiculturalism, Al-Azhar was keen in 1967 to establish the Department of African Languages to teach the most prevalent African languages such as: (Swahili, Hausa, Amharic, Fulani). It aims to achieve a part of the message of Al-Azhar Al-Sharif and its university in these societies, including spreading the true Islam, correcting misconceptions about it, and getting to know the etiquette and cultures of African peoples. Teaching in the department was not limited to the Egyptian faculty members, but it has employed some African-speaking professors who studied in Al-Azhar in the framework of cultural cooperation and communication between Al-Azhar and the African peoples. Al-Azhar also was keen on spreading Islam, a division was established to teach Islamic studies in the Swahili language within the Department of African Languages as the most widespread language in the eastern and central continent. It is taught by the Egyptian and African faculty members from the African continent[18] .

The table number (2) shows that there is a gradual increase in the numbers of students at Al-Azhar University, as a result of establishing the modern Al-Azhar University in accordance with Law No. 103 of 1961 AD. It refers to the establishment of new Al-Azhar colleges and girls 'colleges, which led also to an increase in the numbers of international students studying in AlAzhar from various countries of the world.

In 1968, a petition was sent to Al-Azhar Magazine, requesting the establishment of theoretical colleges for Al-Azhar University in Aswan to serve the people of Upper Egypt and the African continent. It aimed to make these colleges the center of Aswan Al-Azhar University later on [20]Those responsible for Al-Azhar worked to overcome obstacles facing the students to be able to learn the various sciences in its colleges. In addition, Al-Azhar University decided in 1975 to develop a plan to solve the problem of university books by reducing their prices, during the academic year 1974/1975 AD [21].

On Rajab 10, 1395 AH corresponding to 19 July 1975 AD, the University Council, headed by Dr. Muhammad Hassan Fayed, Rector of the University to establish two new departments. These were at the Faculty of Arabic Language, University AlAzhar, namely: (the department for journalism and religious media, and the department for postgraduate studies in religious and modern media). So, on its meeting held on Tuesday, July 22, 1975, the Supreme Council of Al-Azhar, headed by Sheikh Al-Azhar Abdul-Halim Mahmoud, approved the previous decision to spread the Islamic Call. The Department of PostGraduate Studies of Religious Information will accept graduates from Al-Azhar colleges and other universities as well as the expatriates from Islamic and African countries [22].

In 1975, His Eminence the Grand Imam Abdul-Halim Mahmoud, Sheikh Al-Azhar inaugurated the Department of Islamic Journalism and Media at the Faculty of Arabic Language. His eminence delivered the opening speech at the ceremony held on this occasion in Imam Muhammad Abdo's hall. It was witnessed by the leaders of Al-Azhar, its professors and students. He declared that the Islamic press and media is an art... a call that must be honest and follow the guidance of religion. His eminence stated that the syllabus of this department will include the general and Islamic media side by side, in addition to history, foreign languages and Arabic studies [23].

The Egyptian government paid a significant interest to African students at Al-Azhar University, and provided them with all support and facilities. It is noted that they represent a large number of expatriates, and this is due to Al-Azhar's keenness on its basic mission to spread the true Islam and the Arabic language in these countries. It can be also attributed to the lack of educational opportunities for African students in their countries, especially at the university level, and the University of Al-Azhar facilitates their enrollment to it in terms of age, residency and education [4].

\section{Al-Azhar Pre-University Education}

Al-Azhar pre-university education or Al Azhar schools are named "Institutes" and include primary, preparatory, and secondary phases. All schools in all stages teach religious subjects and non-religious subjects. They are considered part of the bodies mentioned in the Al-Azhar Reorganization Regulation in Law No. 103 of 1961. Other institutes may be established by a decision of the competent minister after the approval of the Supreme Council of Al-Azhar.

Azharite scholars assume teaching therein. They aim at providing their students with an adequate amount of Islamic and Arab culture, along with the knowledge and experiences that their counterparts have in other similar institutes. Doing so, they will come out to life provided with its means, supporting their upbringing, revealing their abilities, preparations and inclinations. Students will have sufficient preparation for joining the colleges of Al-Azhar University. Each stage of AlAzhar institutes has a general department of education specializing in the distribution of curricula and academic subjects. All the educational departments of Al-Azhar are united under one administration which is the General Administration of Al-Azhar Institutes which is an independent administration has the right to supervise these Azharite institutes [1،3] 
Before the 1961 Development Law, there were no Azharite institutes in African countries, but there were mosques and kuttabs (institutes for memorizing the Holy Quran) that performed their religious and educational role. Although it was difficult to establish such mosques in African countries, when the opportunity for construction became available, Al-Azhar immediately assisted and accepted donations to contribute to their construction as was the case with the mosque and kuttab of the city of Juba, southern Sudan. However, the situation differed completely after the development law as Azharite institutes were established in African countries, including three in Chad, three in Nigeria, one in Djibouti, one in the Niger, and one in South Africa. These institutes were subject to the technical supervision of Al-Azhar, and were established by a decision of Sheikh Al-Azhar if all conditions applied to them [4]

The period of study in the preparatory institutes of Al-Azhar is four years, during which the student learns religious sciences and language to get the general or technical preparatory certificate. As for the period of study in the secondary institutes of Al-Azhar, they are five years, and in the end the student gets the general secondary certificate in one of its scientific or literary departments or the technical secondary certificate in one of its industrial, commercial, agricultural education or other system. The period of study in the technical secondary departments may be increased or decreased by a decision of the President of the Republic [1].

\section{The Conditions of joining Al-Azhar Institutes include the following- :}

-1The student must be a Muslim, and he must have completed his studies in one of the institutes for memorizing the Qur'an in any Azharite institute or kuttab. He should be a speaker of the Arabic language and familiar with religious sciences. The student has to pass an exam to enroll the preparatory stage. As for the secondary stage, the student has to obtain the preparatory certificate in addition to passing the exam determining his/her religious and linguistic level as well as the extent of memorizing the Holy Quran.

2.The student's age must range between 11 and 16 years old, and be medically fit.

3.It is permissible to accept blind students with all the conditions applied to the seeing students.

4.International Muslim students may be accepted, provided passing an equivalent examination conducted by the General Administration of Al-Azhar Institutes in the Holy Quran, religious and Arabic sciences [4].

According to the executive regulations of the Development Law, a committee is formed from Al-Azhar and the Ministry of Education to approve the subjects taught in these preparatory and secondary Azharite institutes. They set the conditions for admission and the general system of study as well as the exams in these institutes. These institutes have a public administration that is concerned with their management and supervision and the Ministry of Education provides the necessary aid for them. A committee from Al-Azharal-Sharif and the Ministry of
Education is formed to set curricula and plan study subjects in Al-Azhar institutes in accordance with the provisions of the law [1].

The Azharite institutes can be divided into: public Azharite institutes, private Azharite institutes, and Azhar institutes abroad.

-Al-Azhar Public Institutes: They are divided into institutes and societies for memorizing the Holy Qur'an, which are stipulated by law as the nucleus of the primary Azharite institutes. They are two categories, the first of which are schools and societies whose affiliation were transferred from the supervision of the Ministry of Education to Al-Azhar, that assumes spending on them from its budget, providing their needs from teachers, employees, tools and text books. The second category consists of the institutes and societies that AlAzhar supervises technically, provides them with books, and pays an annual subsidy to those in charge of them.

Official Public Institutes: Al-Azhar budget is fully responsible for them, and they form the main Azharite institutes. They include the preparatory and secondary institutes.

Free Public Institutes: These are institutes established by societies of memorizing the Holy Qur'an or the concerned bodies and established the necessary buildings for them. They subject to Al-Azhar that supervises them technically and provides them with some of their needs of teachers and textbooks, as well as providing the money to be able to fulfill their mission [4].

Islamic Missions institute: It was established in Cairo in 1954 for the Muslim students coming from Islamic countries. It is headed by one of the scholars of Al-Azhar that is appointed by a decision of the Supreme Council of Al-Azhar. This is in addition to two deputies to help him and replace him in case of absence. This institute consists of four stages: elementary, preparatory, secondary, and high. It is held as an expression of the interest of Egypt and Al-Azhar in providing them with all means of comfort, and aims to strengthen brotherly relations between the Islamic countries and Egyptians through religion and language. This institute was known before the development in the name of "Al-Qesm al-'Am" or "The General Department", and its students were a mixture of Egyptians and expatriates leaning in Al-Azhar Mosque. Its students included also those whose age did not qualify them to join the regular Azharite institutes.

When the Law of Development was issued in Al-Azhar AlSharif in 1961, it was concerned mainly with students coming to Al-Azhar to educate. SO, it established a special institute for them called the "Islamic Scholarship Institute" that follows AlAzhar institutes sector. If the student does not master the Arabic language, he will be enrolled in the Department of Special Studies at Al-Azhar before his enrollment in the Islamic Missions Institute, which includes preparatory and secondary education. Then, the student joins the colleges of Al-Azhar University [4]. 
After the decision of the President of the Republic regarding the executive regulations governing Al-Azhar Development Law of 1975, the Prime Minister, in his capacity as Minister of AlAzhar Affairs, has all powers to issue decisions that the Supreme Council of Al-Azhar requests to change or amend in the educational system of the Islamic Research Institute. This aims to keep pace with the educational and religious aspect through the plans laid down for education and curricula for each classroom in the education stages of the institute and the Institute of Qira'at (Recitations). The science of Recital of the Qur'anis related to memorizing the Holy Qur'an in this institute to become the main pillar upon which these sciences are taught scientifically and practically. It aims at preserving the science of recitations and knowledge of frequent and anomalous recitations [4].

\begin{abstract}
Al-Azhar Institutes at African Countries: Al-Azhar managed to establish some Al-Azhar institutes in some countries that it can't bring their students to study in Al-Azhar due to their financial conditions that do not allow them to bear the expenses of coming to study in Al-Azhar. After issuing the law, the private Azharite institutes abroad became under the technical supervision of al-Azhar. Sheikh al-Azhar authorized their establishment if they fulfilled all the conditions, specifications and procedures stipulated in the scope of cultural and scientific agreements concluded by Egypt and the countries in which the institutes are established.
\end{abstract}

These institutes aim at memorizing the Noble Qur'an and learning the sciences of Qur'an, the Noble Prophet's Sunna and Arabic language sciences. The institute's location, building, and equipment should be appropriate to the requirements of its mission and conform to the specifications determined by the technical departments of Al-Azhar Al-Sharif. The tenure of Sheikh Al-Azhar Gad Al-Haq witnessed the establishment of three Azharite institutes in Chad, three in Nigeria, one in Djibouti, one in Niger, one in South Africa, two in Somalia, and one in each of Tanzania, Kenya and Eritrea. Each of these institutes operates at the level of the three educational levels of Al-Azhar: primary, preparatory and secondary [24،4]

The study in these institutes runs on the education system in AlAzhar, and is subject to the technical supervision of Al-Azhar. The Research Academy and Al-Azhar Institutes Sector supply these institutes with teachers, books and curricula. The number of these Azharite institutes in Africa has reached thirteen institutes. For example, Al-Azhar institutes in Sudan included Omdurman Religious Institute, Al-Ahfad Institute, the Religious Institute in Halfa, the Religious Institute in the Gordon Tree, the Religious Institute in Malakal and the Juba Institute. As for those in Senegal, they included, the Kaolack Institute and Haji Mortada Institute. In Libya, they included: Al-Bayda Religious Institute and Al-Qweisri Institute, and in Ghana Al-Maqased alIslameya Institute [24].
With regard to the subjects taught in Al-Azhar preparatory institutes for the seeing students: they are (fiqh (jurisprudence), Tawheed Hadith (modern monotheism), Tafsir (interpretation), Insha' (composition), reading and texts, grammar, morphology, biography, calligraphy and dictation, recitation of the Holy Qur'an, in addition to the Ministry's curricula. These include: foreign language, social subjects, mathematics, general sciences and health, art education, physical education and handicrafts for boys. The situation does not differ much for Al-Azhar secondary institutes where the seeing students study: (jurisprudence, interpretation, Hadith, monotheism, grammar and morphology, rhetoric, composition, language literature, poetics and rhyme, reading, memorizing the Noble Qur'an for girls, this is in addition to the curricula of the Ministry. These included: (foreign language, logic, Arab and Islamic society, philosophy, mathematics, science, art education, practical studies, and physical education) as for the blind students in alAzhar institutes, they do not study the subject with the same burden [11]

In the eighth conference of the Islamic Research Academy in 1977 AD, the participating scholars from Al-Azhar Al-Sharif demanded expanding its institutes of various stages in Egypt and abroad in the Islamic countries. It aims to facilitate for foreign students abroad and meet the growing needs of Islamic world to scholars, preachers, and the publications of true Islam [25].

Therefore, it is clear that President Gamal Abdel Nasser worked on developing Al-Azhar Al-Sharif; to enable it to fulfill its mission in Egypt and the Islamic world. Nasser saw it necessity to remove the outcomes of colonialism and addressing the threat of missionaries and what they did in many African countries. Al-Azhar Al-Sharif did not have institutions before the Development Law in $1961 \mathrm{AD}$, and these institutions contributed to the development of the African continent. The most important of these are the Supreme Council of Al-Azhar that is concerned with directing and drawing the general policy of Al-Azhar. It also works on drawing educational policy for Al-Azhar University and institutes and everything related to Islamic studies. Moreover, it works to collect the necessary funds for Al-Azhar in order to achieve its goals in the Islamic world.

One of the most important problems facing the Islamic Culture and Research Department is the weakness of the budget allocated to it, which negatively affected the role of Al-Azhar in Africa at that time. The developed university of Al-Azhar was established, with its scientific faculties such as those of medicine, engineering and agriculture. The university worked on teaching African languages. Moreover, as a result of interest in women's education, girls 'colleges were established in AlAzhar to teach and educate Muslim women.

The Al-Azhar institutes are part of the bodies mentioned in $\mathrm{Al}$ Azhar regulation. These institutes have worked to provide their 
students with sufficient Islamic and Arab culture, to prepare them for admission to the colleges of its University. Al-Azhar also worked on establishing some Azharite institutes in African countries to facilitate the African students' enrollment to them. These included Al-Beouth Institute to international students joining Al-Azhar

Table (1)

Al-Azhar University Spending Rate from 1962 to 1978 [13].

\begin{tabular}{|c|l|l|c|}
\hline $\begin{array}{l}\text { Academic } \\
\text { Year }\end{array}$ & $\begin{array}{l}\text { Appropriat } \\
\text { ions }\end{array}$ & $\begin{array}{l}\text { Academic } \\
\text { Year }\end{array}$ & Appropriations \\
\hline $1962-1963$ & $5,350,000$ & $1970-1969$ & $2,335,300$ \\
\hline $1963-1964$ & $9,814,000$ & $1971-1970$ & $2,588,900$ \\
\hline $1964-1965$ & $1,121,180$ & $1972-1971$ & $2,905,100$ \\
\hline $1965-1966$ & $1,732,700$ & $1973-1972$ & $3,100,232$ \\
\hline $1966-1967$ & $2,204,000$ & $1974-1973$ & $3,460,870$ \\
\hline $1967-1968$ & $1,833,700$ & $1977-1976$ & $3,579,810$ \\
\hline $1968-1969$ & $2,179,700$ & $1978-1977$ & $4,325,621$ \\
\hline Total & & $46,531,113$ \\
\hline
\end{tabular}

* The rates are in the Egyptian Pound.

Table (2):

The number of Students of Al-Azhar University before and after the Development, distributed according to their colleges, including those that were established late [19].

\begin{tabular}{|c|c|c|c|c|c|c|}
\hline $\begin{array}{l}\text { Acade } \\
\text { mic } \\
\text { Year }\end{array}$ & $\begin{array}{l}\text { Faculty } \\
\text { of } \\
\text { Sharia }\end{array}$ & $\begin{array}{l}\text { Faculty of } \\
\text { Fundamen } \\
\text { tals of } \\
\text { Religion }\end{array}$ & $\begin{array}{l}\text { Facult } \\
y \text { of } \\
\text { Arabic } \\
\text { Langu } \\
\text { age }\end{array}$ & $\begin{array}{l}\text { Faculty of } \\
\text { (Transacti } \\
\text { ons and } \\
\text { Managem } \\
\text { ent) } \\
\text { Commerc } \\
\text { e }\end{array}$ & $\begin{array}{l}\text { Faculty } \\
\text { of Girls }\end{array}$ & Total \\
\hline $\begin{array}{c}157 \\
1958\end{array}$ & 1180 & 752 & 1838 & - & - & 3770 \\
\hline $\begin{array}{c}159 \\
1960\end{array}$ & 1016 & 796 & 1853 & - & - & 3665 \\
\hline $\begin{array}{c}/ 62 \\
1963\end{array}$ & 1030 & 800 & 2143 & - & - & 3973 \\
\hline $\begin{array}{c}/ 65 \\
1966\end{array}$ & 1117 & 949 & 2274 & - & - & 4340 \\
\hline $\begin{array}{c}/ 67 \\
1968\end{array}$ & 1483 & 1222 & 2265 & - & - & 4970 \\
\hline
\end{tabular}

\begin{tabular}{|c|c|c|c|c|c|c|}
\hline $\begin{array}{c}/ 70 \\
1971\end{array}$ & 1787 & 1550 & 2416 & - & - & 5753 \\
\hline $\begin{array}{c}173 \\
1974\end{array}$ & 1969 & 1823 & 1982 & 334 & - & 6108 \\
\hline $\begin{array}{c}/ 77 \\
1978\end{array}$ & 2023 & 2140 & 2490 & 622 & 153 & 7428 \\
\hline Total & 40,007 \\
\hline
\end{tabular}

\section{References}

[1]Law No. 103 of 1961 about reorganization Al-Azhar and the bodies it covers. The Egyptian official newspaper. 1961; 153: p. 877, 880, 884. 885.

[2]The Arabic republic of Egypt. Law No. 103 of 1961 about reorganization AlAzhar and the bodies it covers, and its executive regulations issued by the presidential decision No. 250 of 1975. Cairo: General authority for Emiri press affairs; 1975 , p. 1.

[3]Ministry of Endowments and Al-Azhar Affairs. Al-Azhar, its history and development. Cairo: Arab Socialist Union; 1964, p. 485, 486, 498.

[4]Abbas Ahmed M. Al-Azhar and Africa "A Documentary Study". Cairo: International House for Publishing and Distribution; 2004, P. 92, 93, 101, 102 , 104-107.

[5]Al-Azhar Al-Sharif sheikhdom. Sheikhs, agents and presidents of Al-Azhar University. Cairo: The Supreme Committee for the celebration of the Millennium; 1983 p. 284.

[6]Tawfeeq Algondy M. The ancient system of study in Al-Azhar Mosque. Cairo: Al-Azhar; 1965, P. 345-347.

[7]Mohamed Ouf A. Al-Azhar in a thousand years" Islamic Research Series". Cairo: Islamic Research institute; 1970, P. 141-142.

[8]Mahmoud Elsayed A. The future of Al-Azhar after the Arab revolutions. Cairo: Arab institute for Humanitarian Studies; 2003, P. 71.

[9]Abd El-Aleem hussien M. Al-Azhar Al-Sharif sheikhdom, in Al-Azhar AlSharif on its thousandth anniversary. Cairo: Egyptian General Book Authority; 1983, P. 273.

[10]Albahie M. My life is within Al-Azhar, student "professor and minister". Cairo: Wahba Library; P. 73.

[11]Saleh M. The political role of Al-Azhar from 1952 to 1982 [Ph.D.]. Cairo University; 1999. P. 162, 320,335, 521.

[12]Salman A. Al-Azhar cultural role in some African countries [ph.D.]. Ain Shams University; 1972. P. 84.

[13]Al-Ahram newspaper. Al-Azhar University budget statement from 1971 to 1974. 1975 February 6. P. 21

[14]Al-Azhar mosque budget project from 1955 to 1970. Cairo; 2020. P. 3.

[15]Madi M. A. Al-Azhar in twelve years. Cairo: National House for Printing and Publishing; 1964. P. 485.

[16]Khafagy M. Al-Azhar in a thousand years. 3rd ed. Cairo: Algazeera for publishing and distributing; 2011. P. 201.

[17]Medhat N. Sawt Al-Azhar. Cairo; 2018 April 25. P. 5.

[18]Souody O. Al-Azhar Al-Sharif is a pioneering role in the African continent. Cairo: information General Association; 2019 April 16. PP. 1-4.

[19]Al-Azhar University. Planning Committee for the Islamic College of Girls. Cairo: Al-Azhar Foundation; File No. 57; 1962. P. 3.

[20]Journal of Al-Azhar. Part one. Cairo: 1968 April. P. 317.

[21]Journal of Al-Azhar. Part one. Cairo: 1977 March. P. 1010

[22]Elnoiehy I. H. Journal of Al-Azhar. Part sex. Cairo: 1975 August. P. 728.

[23]Journal of Al-Azhar. Part one. Cairo: 1976 January. P. 122.

[24]Al Bargal A. S. H. 1000 information about Al-Azhar Al-Sharif. Cairo: Alfadila Publishing House; 2013. PP. 328, 332.

[25]Al-Azhar Al-Sharif. Islamic Research Academy, its history and development. Cairo: Proceedings the Millennium of Al-Azhar Al-Sharif Conference; 1983. P. 448. 